\title{
INSTRUCTIONS TO AUTHORS.
}

An author is advised to retain a copy of his paper, as the Society cannot undertake any responsibility in relation to the custody of papers entrusted to it. The 'copy' should be written on large sheets of paper, on one side only, and the pages should be clearly numbered. The MS. must be easily legible, preferably typewritten, and must be absolutely in its final form for printing. All tables of contents, references to plates, or illustrations in the text, etc., must be in their proper places, with the page numbers left blank; and spaces must be indicated for the insertion of illustrations that are to appear in the text.

ILLUSTRATIONS.-All illustrations must be drawn in a form immediately suitable for reproduction; and such illustrations as can be reproduced by photographic processes should, so far as possible, be preferred. Drawings to be reproduced as line blocks should be made with Indian ink (deadened with yellow if of bluish tone), preferably on fine white bristol board, free from folds or creases; smooth, clean lines, or sharp dots, but no washes or colours, should be used. If the drawings are done on a large scale, to be afterwards reduced by photography, any lettering or other legend must be on a corresponding scale.

If an author finds it inconvenient to furnish the drawings according to these regulations, the Society will have the figures re-drawn and the lettering entered at his expense; but this will cause delay.

When the illustrations are ta. form plates, a scheme for the arrangement of the figures (in quarto plates for the Transactions, in octavo for the Proceedings) must be given, and numbering and lettering indicated.

Proofs.-A first proof and, if desired, a revise of each paper will be sent to the author, whose address should be indicated on the MS. Expenses for proof correction should not exceed 10 per cent. of the printers' charges on the setting and printing of each paper. Any excess will be charged against the author.

All proofs must, if possible, be returned within one week, addressed to The Secretary, Royal Society, 22 George Street, Edinburgh, and not to the printer. To prevent delay, authors residing abroad should appoint someone residing in this country to correct their proofs.

The author receives fifty of the reprints free, and may have any reasonable number of additional copies at a fixed scale of prices which will be furnished by the printer, who will charge him with the cost. To prevent disappointment, especially if the paper contains plates, the author should, as soon as possible, notify to the Secretary the number of additional copies required, and should also repeat the notification on the first proof returned.

INDEX SLIPS.-In order to facilitate the compilation of Subject Indices, and to secure that due attention to the important points in a paper shall be given in General Catalogues of Scientific Literature and in Abstracts by Periodicals, every author is requested to return to the Secretary, along with the proof of his paper, a brief index (on the model given below) of the points in it which he considers new or important. These indices will be edited by the Secretary, and incorporated in Separate Index Slips, to be issued with each part of the Proceedings and Transactions.

\section{MODEL INDEX.}

Sharpey-Shafer, E.-On the Existence within the Liver Cells of Channels which can be directly injected from the Blood-vessels. Proc. Roy. Soc. Edin., vol.

Cells, Liver, - Intra-cellular Canaliculi in.

E. Sharpey-Shafer. Proc. Roy. Soc. Edin., vol.

Liver,-Injection within Cells of.

E. Sharpey-Shafer. Proc. Roy. Soc. Edin., vol.

$1902, \mathrm{pp}$.

, 1902, pp.

, 1902, pp. 
No.

XXIV. The Electrosynthesis of $n$-Duotriacontane Dicarboxylic Acid. By David A. Fairweather, B.Sc., Ph.D., Chemistry Department, Edinburgh University. Communicated by Professor Sir JAMES WALKER, F.R.S., . 283

(Issued separately August 26, 1925.)

XXV. Some Points in the Anatomy of Dicksonia. By Samuel Williams, M.Sc., Lecturer on Plant Morphology, Glasgow University. Communicated by Professor F. O. Bower, F.R.S. (With Two Plates and Four Textfigures),

(Issued separately September 24, 1925.)

XXVI. On the Vertical Force Changes during the "Sudden Commencement" of a Magnetic Storm. By A. CRICHTox Mitchell, D.Sc. (With One Plate), . . . . 297

(Issued separately September 24, 1925.)

XXVII. A Colour-Vísion Spectrometer. By Professor W. Peddie, D.Sc.,

(Issued sepurately September 24, 1925.)

XXVIII. A Ball-and-Tube Flowmeter. By Sir J. Alfred Ewing, K.C.B., F.R.S., President. (With Three Plates and Six Text-figures),

(Issued separately September 24, 1925.)

The Papers published in this part of the Proceedings may be had separately, on application to the Publishers, at the following Prices:-

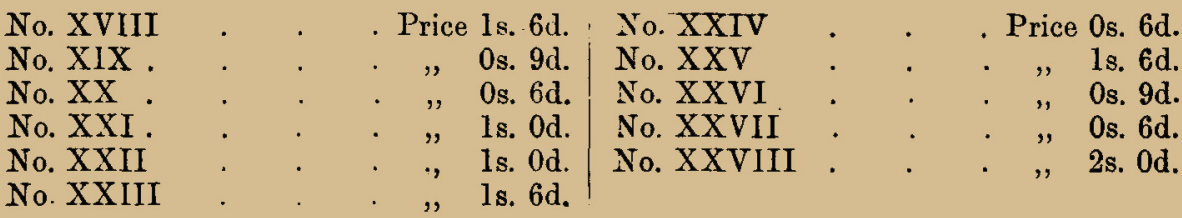

